\title{
The Belgian participation in the Milan Triennials
}

\author{
FLORÉ, Fredie / PhD / Ghent University, Belgium and VU University Amsterdam / the Netherlands
}

Belgium / Milan Triennials / Industrial design / Design exhibitions

The Milan Triennials were a series of international exhibitions on design, fine arts, architecture and urban planning. Their history dates back to 1923 and includes several historical episodes. Since the beginning Belgium was a regular participant in the Milan Triennials. This paper discusses the Belgian sections from the early 1920 to the late 1950s and sheds a light on the changing approach in exhibiting the cultural and economical production of the nation.

The Milan Triennials are a series of international exhibitions on design, fine arts, architecture and urban planning with a history that dates back to 1923. Within the field of design history several national entries in these exhibitions have been thoroughly discussed. For example this is the case with the Swedish, Danish, Norwegian and Finnish sections of the 1950s, which played a key role in the promotion of 'Scandinavian modern' (Halen and Wickman 2000). Other national entries are less well known, such as the Belgian ones. Nevertheless since the beginning Belgium was a regular participant in the Milan Triennials. During several decades the national authorities considered their participation as an important form of cultural and economical export.

Unlike the Scandinavian example, the impact of the Belgian entries on the international design production and debates turned out to be rather limited. However, as this paper will show, a study of the Belgian sections from the early 1920 to the late 1950s sheds an interesting light on the way the country exhibited its cultural and economical production.

\section{Belgium: an early and regular participant}

The Triennials, of which the first edition was organized in 1930, was the successor of the 'Mostra Internazionale delle Arte Decorative' held every two years in the Villa Reale in Monza (Pansera, Venturelli and Mastrobuono 1985). Since the first edition of the Monza biennial in 1923 until the Milan Triennial of 1964, Belgium was regularly represented on these international events, except for two editions ( 1927 and 1940). At first it was the Belgian Ministry of Science and Art and the Commission of the Royal Museums of Fine Art who organized the Belgian entries ( $X 1923, X$ 1925). The aim was to underline the importance of the nation's art history and to promote the work of a selection of contemporary artists, interior decorators and architects (X 1923). The Belgian entries of the first two biennials showed applied arts and architecture by established architects and designers such as Albert Van Huffel, Paul Hankar, Victor Horta or Henry Van de Velde. However, there was also room for experimental work, such as the modern interior presented by the avant-garde group 7arts with furniture designed by architect Victor Bourgeois and lightning by Marcel-Louis Baugniet (Pica 1957, Strauven 2005).

Since its official start in 1930 the Triennial explicitly intended to broaden the scope of the earlier international exhibitions in Monza. Instead of focusing on 'decorative arts' the new exhibition title 'Esposizione internationale d'arte decorativa e Industriale Moderna' - clearly indicated that from now on decorative and 'modern industrial arts' would be on show (X 1930). This change in focus was paralleled by a change in the organization of the Belgian section. From 1930 onwards the responsibility of representing the Belgian nation moved from the Ministry of Science and Art to the Ministry of Economic Affairs. Nevertheless the nature of the national section only slightly changed. In the 1930 s the exhibition architects for example still used the format of the furnished model room. However it should be noted that an increasing amount of large Belgian companies participated, such as furniture firm De Coene, the department stores Grand Magasins du Bon Marché and Vanderborght or the crystal glassware manufacturer Val Saint Lambert.

After the Second World War the organization of the Milan Triennials regularly dedicated the international exhibitions to a specific theme: 'housing for all', 'the house and the school', 'leisure' $\varepsilon$ Most post-war Belgian entries showed the ambition to respond to these themes. The Belgian Ministry of Economic Affairs remained one of the key organizers of the national sections, although on several occasions it collaborated with different experts to properly address the topic at hand. For example, to deal with the theme 'housing for all' of first post-war Milan Triennial (1947), the organizing committee of the Belgian section also included representatives of social housing organizations and institutions. That year's national entry was designed by architects Victor Bourgeois and Louis-Herman De Koninck and consisted of a presentation of products of Belgian companies, a fully furnished model apartment for a middleclass family and an exhibition on the possibilities of so-called 'economic building' (X 1947).

In the course of the fifties the Belgian entries developed an explicit interest in industrial design. A close reading of these entries, this paper argues, shows the authorities' gradual recognition of the discipline of industrial design (Martinez 2009) and as a result the changing demands towards exhibition architecture.

\section{The Belgian sections of the 1950 s: architecture and industrial design}

According to many critics the Belgian entry of 1951 was a very problematic one. Architecture and design critic Pierre-Louis Flouquet explained that many professionals condemned the 'aston- 
ishing concept' of the national section in the Palazzo dell'Arte (Flouquet 1951). Contemporary photographs show a very dense compilation of craftwork, glassware, modern furniture, a large stained glass window, a sculpture of Saint Francis, etcetera. According to architect Jean Hendrickx the problem was not so much the quality of the products, but the way the products were combined and presented (Hendrickx 1951). The exhibition layout lacked direction, form and style, he claimed. Perhaps the most unifying element of the exhibition design was its use of color. After all, the dominant colors were red, black and yellow, explicitly referring to the Belgian flag. More unity was found in the Belgian participation in the experimental housing district QT8, which was linked to the same edition of the Milan Triennial. On this offsite location the SBUAM (Belgian Society of Modernist Urban planners and Architects) was assigned to build a 'Casa Belga', a full-scale model house furnished with Belgian design, especially furniture. Contrary to the Belgian section in the Palazzo this modernist house was much more appreciated by the professional press and according to some critics allowed Belgium to 'save face' (Hendrickx 1951).

The 1954 edition of the Milan Triennial in general was marked by an increasing interest in 'industrial design'. This also showed in the Belgian section, which focused on the theme 'the honor of mankind and his work' (Aars 1954). Possibly in response to the criticism of the 1951 entry, the 1954 section consisted of a quite minimal installation, designed by architect De Poerck, which mainly consisted of a partly elevated floor, a few tables and a spatial composition of several laminated timber beams (Devos \& Floré 2006). On show were not only domestic objects and crafts (again including products by Val Saint Lambert), but first and foremost technical instruments, such as microscopes, cameras, chirurgical instruments and even guns. The layout of the Belgian entry was awarded with a 'diploma of honour' and several products on display received golden, silver or honorary medals (Sosset 1954). According to design critic Leon-Louis Sosset this form of recognition was important because it would strengthen the position of the slowly emancipating discipline of 'industrial design' in Belgium (Sosset 1954). Indeed, at the time there were only a few smallscale organizations or initiatives supporting the development of industrial design. From the mid 1950s onwards, stimulated by the policy of Minister of Economic Affairs Jean Rey, the discipline gradually gained recognition with for example the establishment in 1957 of the quality label Le Signe d'Or for products made in the Benelux (De Kooning \& Strauven 2000; Martinez 2010). The Italian Compasso d'Oro, established in 1954, served as an example.

As in the previous edition the Belgian section of the 1957 Milan Triennial combined an airy and serene exhibition architecture with the display of a limited selection of craftwork and especially industrial products (X 1957). This time architects Lucien Kroll and Charles Vandenhove, both involved in the recently established Institut d'Esthétique Industrielle (Institute of Industrial Design), were responsible for the overall layout of the national entry. They organized the exhibition space using several orthogonally placed wall panels while combining the exhibition objects into smallscale ensembles. Among the exhibited products were several furniture pieces designed by the self-made designer Jules Wabbes (Ferran-Wabbes 2010). The combination of his sophisticated, modern (office) tables with industrial products like a shotgun, a milking machine or professional measuring equipment and large prints of the almost abstract photographical work of Serge Vandercam resulted in interior settings, which barely remind us of the model rooms or model apartments presented in previous editions of the Milan Triennials or in the then popular home educational exhibitions in Belgium (Floré 2004a, Floré 2004b). The Belgian section of the 1957 Milan Triennial showed industrial design as a fully recognized export product of the Belgian state and exhibition architecture as a design discipline, which had liberated itself from the dominant formula of the model room.

\section{Conclusion}

The Belgian entries of the Milan Triennials illustrate the emergence of industrial design as a cultural and economic representation of the Belgian state. Although at the home front it would still take some time before the discipline became officially recognized, within the context of international exhibitions by the late 1950s the Ministry of Economic affairs clearly chose to present Belgium as a country with a high quality output in industrial design. This also showed in the 1958 World's Fair in Brussels where a specific exhibition within the Belgian Section was devoted to the objects selected by Le Signe d'Or.

At the same time a study of the post-war Belgian entries of the Milan Triennials show that the emergence of industrial design as a product of national prestige required a different approach in terms of exhibition architecture. In response to the increasing diversity of the objects on display (from chairs to shotguns), architects were challenged to develop other presentation formats next to that of the model house.

\section{Acknowledgment}

The author wishes to thank Veerle Schoutteet and Hanne Vandenhende for collaborating on the research on the history of the Milan Triennials.

\section{References}

Aars, F. 1954. XT: 10 Triennale di Milano. Milan: Edizioni della Triennale.

De Kooning, M. \& Strauven I. 2000. Het fifties-meubel in België, in: De Kooning, M., Flore, F. \& Strauven, I. (eds.), Alfred Hendrickx en het fifties-meubel in België. Mechelen: Stedelijke Musea Mechelen: 9-49.

Devos, R. \& Flore, F. 2006. La modernité avec De Coene. La production après 1952. In: Les Ateliers d'Art de Courtrai De Coene Frères: 80 ans d'artisanat et d'industrie - mobilier - intérieurs - architecture. Brussels: Le Livre Timperman: 183-20?.

Ferran-Wabbes, M. 2010. Jules Wabbes. Gent: Borgerhoff \& Lamberigts.

Flore, F. 2004a. Lessen in Modern Wonen. Bronnenboek over Woontentoonstellingen in België. 1945-1958. Lessons in Modern Living. Source Book 
on Housing Exhibitions in Belgium. 1945-1958. Ghent: WZW Editions and Productions.

Flore F. 2004b. Lessons in Modern Living. Home Design Exhibitions in Belgium 1945-1958. The Journal of Architecture 4: 445-462.

Flouquet, P.-L. 1951. La 9ème Triennale de Milan. La Maison 7 (12): 385

Halen, W. \& Wickman K. (eds.) 2000. Scandinavian design beyond the myth: fifty years of design reform in the Nordic countries. Stockholm: Arvinius.

Hendrickx, J. 1951. La Triennale des arts décoratifs et de l'architecture modern de Milan. L'Habitation 8: 41-42.

Martinez, J.G. 2009. The introduction and dissemination of the English word 'design' in the Belgian context. In Fujita, H. (ed.), Words for design II, Osaka: Japan Society for the Promotion of Science: 53-59.

Martinez, J. G. 2010. The Signe d'Or Award Scheme from 1956 to 1960: the Economic Reasons for Good Design. Journal of Art History 3: 127-145.

Pansera, A., Venturelli, A. \& Mastrobuono, A. C. 1985. The Triennale of Milan: Past, Present and Future. Design Issues, 2 (1): 23-32.

Pica, A. 1957. Storia della Triennale 1918-1957. Milan: Edizione del Milione.

Sosset, L.-L. 1954. Sierkunsten en nijverheidstechniek. De lessen der 10e Triennale van Milaan. Kunstambachten en kunstnijverheden 5 (60): 3.

Strauven, I. 2005. De gebroeders Bourgeois: architectuur en plastique pure. Brussel: AAM.

$X$ 1923. Prima esposizione internationale delle arti decorative: Consorzio Milano-Monza Umanitaria: maggio-ottobre 1923. Milan: Bestetti e Tumminelli.

X 1925. Catalogo seconda mostra internationale delle arti decorative. Villa Reale di Monza, maggio-ottobre 1925. Milan: Case Editrici Alpes/F. De Rio.

X 1930. Catalogo ufficiale della 4 esposizione triennale internazionale delle arti decorative et industriale modern: maggio-ottobre 1930. Milan: Casa Editrice Ceschina.

X 1947. La 8ième Triennale de Milan. La Maison 3 (?): 14 ?.

X 1957. XI Triennale di Milano, sezione Belga. Brussels: Ministerie van Economische Zaken.

\section{About the author[s]}

Fredie Floré is assistant professor in architectural history at VU University Amsterdam and post-doctoral researcher at the Department of Architecture and Urban Planning, Ghent University. Her research focuses on the history of (educational) discourses on domestic architecture, home culture, interior and design in Belgium in the second half of the 20th century.<fredie.flore@ugent.be> 